УдК 343.98

\author{
Ю. М. Чорноус
}

\title{
МІЖНАРОДНА ЗЛОЧИННІСТЬ: АКТУАЛЬНІ ЗАВДАННЯ ДЛЯ КРИМІНАЛІСТИЧНОЇ МЕТОДИКИ
}

Постановка проблеми. На проблемах боротьби з міжнародною злочинністю, що становить загрозу як усьому світовому товариству, так й окремим державам, основним правам і свободам людини, постійно наголошується в актах нормотворчості, виступах посадових осіб, наукових працях, публіцистиці. Мова йде про підвищення ії суспільної небезпеки, заподіюваної шкоди. Злочинність стає все більше організованою, озброєною, корумпованою, інтелектуальною, оперативно використовує досягнення науки й техніки для реалізації своїх цілей.

Мета статті - довести важливість опрацювання криміналістичної методики розслідування найбільш небезпечного виду злочинності - міжнародної.

Виклад основного матеріалу дослідження. Свій вагомий внесок у забезпечення боротьби з міжнародною злочинністю має зробити й криміналістика. Безпосередньо в контексті розглядуваних питань - це криміналістична методика розслідування злочинів, що являє собою систему інтегрованих наукових положень і сформованих на їх основі методичних рекомендацій, які забезпечують оптимальну організацію розслідування окремих видів злочинів і запобігання їм.

Термін «міжнародна злочинність» варто розглядати як узагальнене поняття, що об'єднує найбільш небезпечні злочини, які посягають на інтереси держав або всього світового співтовариства, основні права та свободи людини. Зокрема, в такому значенні він використовується за змістом міжнародних договорів України, де наголошується на готовності нашої держави співробітничати з іноземними державами в боротьбі з міжнародною злочинністю (тероризмом, незаконним обігом наркотичних засобів i психотропних речовин, нелегальною міграцією, незаконним обігом вогнепальної зброї, боєприпасів, вибухових і радіоактивних речовин, торгівлею людьми тощо).

У літературі традиційною є думка, що міжнародна злочинність складається з двох основних елементів: міжнародних злочинів і злочинів міжнародного характеру [1, с. 14]. 
Найвищий ступінь притаманний міжнародним злочинам - особливо небезпечним для людської цивілізації порушенням принципів і норм міжнародного права, що мають основоположне значення для забезпечення миру, захисту особи й життєво важливих інтересів міжнародного співтовариства загалом [2, c. 53]. Уперше визначення та перелік міжнародних злочинів наданий у Статуті Міжнародного військового трибуналу 1945 року й аналогічному Статуті для Далекого Сходу 1946 року. Особливою є реалізація кримінального судочинства щодо міжнародних злочинів, яка раніше відбувалася в межах діяльності спеціально створених трибуналів (Нюрнберзький, Югославський, Руандійський), а нині такої компетенції набув Міжнародний кримінальний суд [3].

Отже, системоутворювальним елементом міжнародної злочинності є міжнародні злочини. Однак кількість цих злочинів відносно невелика, і в чистому вигляді вони практично не зустрічаються [4, с. 56]. Частіш за все ці злочини пов'язані з іншими діяннями злочинного характеру, які виходять за межі однієї або кількох держав, посягають на державні або суспільні інтереси, особу, їі права і свободи. Питому вагу міжнародної злочинності становлять саме злочини міжнародного характеру.

Юридична енциклопедія під редакцією Ю.С. Шемшученка визначає, що основна особливість розглядуваної групи злочинів полягає в тому, що відповідальність за їх учинення передбачена міжнародними договорами універсального або регіонального значення. Конкретні заходи покарання за вчинення злочинів міжнародного характеру визначаються національним законодавством після інкорпорування міжнародного договору [5, с. 615].

До злочинів міжнародного характеру належать тероризм; захоплення заручників; торгівля людьми; катування; порушення рівноправності громадян залежно від їхньої расової, національної належності або ставлення до релігії; злочини проти осіб та установ, які користуються міжнародним захистом; легалізація (відмивання) доходів, одержаних злочинним шляхом; фальшивомонетництво; контрабанда; незаконний обіг наркотичних засобів, психотропних речовин і прекурсорів; нелегальна міграція; корупційні злочини; посягання на культурні цінності; поширення порнографіі; незаконне поводження з ядерними матеріалами; порушення авторських і суміжних прав; кіберзлочини; створення організованих злочинних організацій; корупційні злочини; піратство; злочини проти безпеки морського судноплавства та цивільної авіації; найманство тощо.

Назви вказаних видів злочинів є узагальненими, адже враховують положення міжнародних договорів і національного законодавства. Відповідно, кваліфікація окреслених злочинів міжнародного характеру за Кримінальним кодексом України підлягає уточненню в кожному конкретному випадку.

Варто додати, що сьогодні все частіше вчинюються й «звичайні» загальнокримінальні злочини 3 «іноземним елементом» або «міжнародними зв'язками», які мають високий рівень суспільної небезпеки, посягають на інтереси кількох держав і їхніх громадян, із цих позицій викликають підвищений суспільний резонанс, зумовлюють особливості розслідування, застосування заходів міжнародного співробітництва. 
Загалом межа між злочинами міжнародного характеру й іншими злочинами 3 «іноземним елементом» є непостійною. Мова йде про те, що практично кожен злочин може набувати міжнародного характеру, якщо матиме високий ступінь суспільної небезпеки для світової співдружності, відповідний об'єкт, предмет злочинного посягання, спосіб учинення. Крім того, варто враховувати, що відмежувати в чистому вигляді «злочини міжнародного характеру» від інших злочинів досить складно, а іноді й неможливо. Так, наприклад, умисне вбивство, службові підроблення, розкрадання у великих розмірах часто є складовими елементами системи злочинної діяльності, що має міжнародний характер.

Підкреслимо, що стосовно всіх указаних груп злочинів існує потреба опрацювання криміналістичної методики розслідування. Попри їх різноманітність, вони мають й спільні ознаки, що полягають у суспільній небезпеці, яка заподіює шкоду суспільним відносинам із різних сфер суспільного життя й міжнародного правопорядку; міжнародній протиправності, закріпленій за змістом міжнародних договорів; караності, визначеній у нормах національного законодавства; реалізації завдань кримінального провадження компетентними органами держав.

Тим більше що останні події, які відбуваються в Україні та світі, зумовлюють новий підхід до організації й тактики розслідування злочинів, що вчиняються на міжнародному рівні. Так, сумнозвісними $є$ події на Сході України 17 липня 2014 року, а саме аварія авіалайнера, що виконував рейс МН-17 Малайзійських авіаліній, унаслідок чого загинуло 298 осіб із різних держав світу, обумовили об'єднання держав у боротьбі зі спільним злом, створення першої у вітчизняній практиці спільної слідчої групи (JIT). До iï складу ввійшли представники Австралії, Бельгії, Малайзії, Нідерландів та України, міжнародні організації. 3 українського боку залучені співробітники Генеральної прокуратури України, Київського науково-дослідного інституту судових експертиз, інших компетентних органів.

У вересні 2016 року слідча група оголосила попередні результати своєї роботи [6]. В офіційному звіті зазначається, що протягом тривалого періоду часу в розслідуванні брало участь від 100 до 200 слідчих і експертів. За два роки найскрупульознішим чином розслідувано вміст десятків контейнерів з тисячами фрагментів та уламків. 1448 фрагментів унесені до бази даних як речові докази. До більше ніж 20 країн направлено 60 запитів про правову допомогу. Досліджено двадцять різних систем озброєння. Зафіксовано п'ять мільярдів сторінок Інтернету, проведено ретельне дослідження й фіксацію півмільйона матеріалів відеозйомок і фотографій, допитано понад 200 свідків. Крім того, прослухано 150000 записаних телефонних розмов, зміст яких коротко викладений і досліджений. У зв'язку з цим понад 3500 із цих прослуханих телефонних розмов повністю й ретельно зафіксовано, перекладено та проаналізовано. Усе це оформлено в понад 6000 протоколів.

Слідча група (JIT) провела грунтовне розслідування, досліджуючи низку версій. Велике значення надавалося залученню експертів і проведенню 
експертиз. Саме завдяки криміналістичним експертизам удалося встановити, що авіалайнер рейсу $M$ Н-17 збитий ракетою серії 9M38. Також група фахівців відвідала в червні 2015 року зону катастрофи, де експерти відібрали зразки грунту з різних місць, які фігурували як можливі місця запуску. Зразки передані на експертизу в Нідерландський інститут криміналістичної експертизи (NFI). На місці здійснені заміри мереж для визначення місць і діапазону сигналів стільникових веж, інші заходи.

Сьогодні в межах розслідування визначено й установлено приблизно сто осіб, які тим чи іншим чином можуть бути пов'язані зі злочинними діями щодо авіалайнера рейсу МН-17 або транспортування зенітного комплексу «БУК». Скільки ще часу займе кримінальне розслідування, сказати складно, це залежить від подальшої узгодженої діяльності з розслідування. Нині угоду про роботу слідчої групи JIT продовжено, й вона буде докладати спільні зусилля, спрямовані на успішне завершення розслідування [7].

Однак, як свідчить вивчення емпіричних джерел, українська сторона зіштовхнулася 3 низкою труднощів, пов’язаних із організацію розслідування, тактикою проведення процесуальних дій, залученням спеціалістів і проведенням експертиз. За цим напрямом потрібні грунтовні напрацювання.

Саме розробка відповідних криміналістичних методик дасть змогу розробити систему наукових положень і розроблених на їх основі рекомендацій з організації та проведення розслідування окремих злочинів і запобігання окремим злочинів, які охоплюються узагальненим поняттям «міжнародна злочинність».

Р.С. Бєлкін зазначав, що криміналістична методика потребує повного врахування суспільних явищ і їх наслідків, які зумовлені науково-технічним прогресом, загостренням ідеологічної боротьби, проблемами економічного та демографічного характеру. Указані завдання потребують більш гнучкого підходу до вибору підстав для розробки комплексу криміналістичних рекомендацій, розробки таких методичних комплексів на базі криміналістичних класифікацій злочинів, які не тільки визначаються, а й реалізуються в криміналістичній методиці повною мірою [8, с. 211]. Наведені слова не лише не втратили, а й набули особливої актуальності відповідно до сучасних реалій.

Побудова криміналістичної методики розслідування злочинів передбачає виявлення та дослідження додаткових ознак, які зумовлені не тільки складом злочину, а й криміналістичними особливостями для окремих видів (груп) злочинів. Опрацювання таких даних розширює наукові уявлення про сутність розглядуваних злочинів, створює передумови для залучення ефективних методів і засобів розслідування, сприяє підвищенню ефективності й оптимізації відповідної діяльності з урахування їх специфіки.

Указаним злочинам притаманні й спільні криміналістичні ознаки, які можуть бути використані під час побудови криміналістичної характеристики злочинів відповідно до предмета злочинного посягання, способу вчинення злочину, обстановки вчинення та слідової картини злочину, особи злочинця й особи потерпілого. 
Постає питання: що ж об’єднує всі перелічені вище злочини й, відповідно, повинно бути враховано під час формування їх криміналістичної методики розслідування? Особливим серед низки ознак є те, що будь-які елементи криміналістичної характеристики злочинів можуть мати ознаки причинного зв'язку з «іноземним елементом», що виражається в предметі злочинного посягання, способі вчинення злочину, обстановці, слідовій картині злочину, особі злочинця та потерпілого. Відповідно, під час учинення злочину, що порушує інтереси кількох держав, міжнародними договорами, учасницею яких $€$ Україна, передбачена універсальна (тобто така, що не залежить від місця вчинення злочину і громадянства винної особи) юрисдикція [9, с. 37]. Тому за будь-яких умов наявність «іноземного елемента» впливає на методику розслідування злочинів, безпосередньо організацію розслідування.

Вивчення наукових джерел свідчить, що структура методики розслідування окремого виду (групи) злочинів може бути визначена відповідно до таких основних елементів, як криміналістична характеристика злочину; обставини, що підлягають з'ясуванню; типові слідчі ситуації й дії на початковому етапі розслідування; наступний етап розслідування й тактика окремих слідчих (розшукових) дій; профілактична діяльність.

Слушним є зауваження, що елементами системи в криміналістичній методиці повинні бути не криміналістичні прийоми та засоби, не слідчі чи інші дії, а криміналістичні (методичні) рекомендації, тобто науково обгрунтовані та апробовані практикою поради, які стосуються організації розслідування, вибору й застосування техніко-криміналістичних засобів $\mathrm{i}$ криміналістичних прийомів. При цьому криміналістична методика і криміналістичні методичні рекомендації співвідносяться як загальне й окреме [10, c. 277].

Розробка криміналістичних рекомендацій як завдання криміналістичної методики розслідування злочинів підкреслюється в роботах вітчизняних вчених. Так, на думку В.О. Коновалової, методика розслідування в практичному значенні покликана забезпечити слідчого необхідними науковими рекомендаціями, що сприяють прийняттю своєчасних правильних рішень із визначення напрямів і конкретних засобів досягнення істини в кожній справі [11, с. 245]. В.А. Журавель переконує, що методику розслідування злочинів можна охарактеризувати як сукупність порад щодо найбільш ефективних шляхів здійснення діяльності [12, с. 57].

Як відзначає С.С. Чернявський, кожна окрема методика як певна програма розслідування має будуватись з урахуванням методологічних засад: 1) предмет методики розслідування злочинів обумовлений особливостями криміналістичної характеристики; 2) зміст кожної методики визначають особливості пошуково-пізнавальних процесів, що мають свою специфіку на різних етапах розслідування й кожен із них характеризується кваліфікаційними, процесуальними, оперативно-розшуковими, організаційно-управлінськими, профілактичними завданнями; 3) в основі криміналістичної методики - алгоритми й програми проведення слідчих і процесуальних дій, оперативно-розшукових заходів і їх комплексів (тактичних операцій), 
спрямованість і послідовність яких залежать від ситуацій розслідування [13, c. 274].

Дискусії щодо сутності криміналістичної характеристики та їі місця в структурі методики розслідування злочину вже тривалий час відбуваються на сторінках наукової літератури. Зі свого погляду хочемо підкреслити вагоме значення криміналістичної характеристики для методики розслідування злочинів, оскільки вона є інформаційною моделлю злочину, відображає його криміналістично значущі ознаки, є предметом наукових досліджень, використовується в практичній діяльності.

У структурі криміналістичної методики увага повинна бути звернена на обставини, що підлягають з'ясуванню. Ст. 91 Кримінального процесуального кодексу України визначає перелік обставин, які становлять предмет доказування й обов'язково підлягають з'ясуванню. Крім того, під час розслідування розглядуваних злочинів коло таких обставин $є$ ширшим, що зумовлюється конкретним видом злочинного діяння, слідчою ситуацією, наявністю міжнародного елемента тощо.

Методика розслідування злочинів розглядається згідно з певними етапами реалізації поставлених завдань. Погляди щодо виділення початкового та наступного етапів розслідування відображено в роботах В.В. Тіщенка [15, с. 176-222] та інших учених. Як відзначає А.Ф. Волобуєв, проблема періодизації розслідування в криміналістичній методиці - це передусім теоретична проблема. Її вирішення пов'язане з розробкою більш чіткої структури методики розслідування окремих видів злочинів, що має як науково-дослідне, так і дидактичне значення. Разом із тим ця проблема має й досить виразний практичний аспект. Етапи розслідування в окремій методиці повинні реально відбивати змістові особливості роботи слідчого за кримінальною справою на певних ії проміжках. Це неможливо без урахування процесуальних рішень, що приймаються за кримінальною справою, бо вони є ознаками вирішення (чи невирішення) певних завдань розслідування [14, с. 148].

Уважаємо, що наведений поділ актуальний і стосовно криміналістичної методики розслідування злочинів, які входять до структури міжнародної злочинності.

Початковий етап розслідування злочинів за цих умов має на меті з'ясування характеру злочину, змісту посягання на міжнародні й національні інтереси, встановлення причетних до вчинення злочину осіб. Цей етап максимально пов'язаний із дослідженням інформації, що відображена в слідах злочину, предметах, які піддавалися злочинному впливу, у показаннях свідків-очевидців тощо. За сучасних умов злочинці намагаються зменшити ймовірність залишення слідів під час учинення злочинних дій, що зумовлює застосування нових технічних засобів і методик роботи зі слідами злочину.

Ефективному досягненню поставлених завдань під час розслідування злочинів може сприяти забезпечення організації одночасного розслідування цих злочинів правоохоронними органами кількох іноземних держав, 
якщо вони підпадають під дію відповідної юрисдикції. Міжнародна практика свідчить, що одночасне порушення кримінальних справ (проваджень) щодо злочинів міжнародного характеру компетентними органами кількох держав, проведення ними погоджених заходів, спрямованих на одночасне затримання злочинців, установлення свідків, виявлення та збирання доказів, забезпечує проведення повного, об'єктивного розслідування в максимально стислі строки [16, с. 57].

Висновки. Методика розслідування злочинів, що становлять «міжнародну злочинність», з практичного аспекту повинна бути спрямована на розробку рекомендацій, які регламентуватимуть діяльність компетентних суб'єктів на початковому й наступному етапах розслідування, організацію міжнародного співробітництва, відповідно до слідчих ситуацій розслідування окремих видів (груп) злочинів.

\section{Література}

1. Зелінська Н.А. Міжнародно-правова концепція міжнародного злочину : автореф. дис. ... докт. юрид. наук : спец. 12.00.11 «Міжнародне право» / Н.А. Зелінська. - К., 2007. - 37 с.

2. Панов В.П. Международное уголовное право : [учебное пособие] / В.П. Панов. - М. : Инфpa-M, 1997. - 320 c.

3. Римский статут международного уголовного суда (статус), принят 17 июля 1998 года, по сост. на 15 мая 2009 г. [Электронный ресурс]. - Режим доступа : http:/ / zakon1.rada.gov.ua/cgibin / laws / main.coi? nreg=995_i40.

4. Цепелев В.Ф. Международное сотрудничество в борьбе с преступностью: уголовно-правовые, криминологические и организационно-правовые аспекты : [монография] / В.Ф. Цепелев. - М. : Акад. управл. МВД России, 2001. - 137 с.

5. Юридична енциклопедія : в 6 т. / редкол. : Ю.С. Шемшученко (гол. редкол.) та ін. - К. : Укр. енцикл., 1998-2004. - Т. 2 : Д-Й. - 1999. - 741 с

6. Телеканал новин «24» [Електронний ресурс]. - Режим доступу : http://24tv.ua/.

7. Звіт Міжнародної слідчої групи щодо рейсу МН-17 [Електронний ресурс]. - Режим доступу : http:/ / ukr.lb.ua/news/2016/09/28/346430_zvit_mizhnarodnoi_slidchoi_grupi_shchodo.html.

8. Белкин Р.С. Курс советской криминалистики : [пособие для вузов МВД СССР] : в 3 т. / Р.С. Белкин ; Акад. МВД СССР. - М. : Акад. МВД СССР, 1977-1979. - Т. 3 : Криминалистические средства, приемы и рекомендации. - 1979. - 408 с.

9. Науково-практичний коментар Кримінального кодексу України від 5 квіт. 2001 р. / за ред. M.I. Мельника, M.I. Хавронюка. - K. : Каннон ; А.С.К., 2001. - 1104 с.

10. Щур Б.В. Джерела та особливості реалізації криміналістичних методичних рекомендацій / Б.В. Щур / / Вісник Луганського державного університету внутрішніх справ: наук-теорет. журнал. - Луганськ, 2011. - № 1. - С. 273-279.

11. Коновалова В.Е. Актуальные проблемы тактики и методики расследования преступлений / В.Е. Коновалова / / Коновалова В.О. Вибрані твори / В.О. Коновалова. - Х., 2012 - С. 239-247.

12. Журавель В.А. Криміналістичні категорії: традиції та новації (деякі дискусійні питання) / В.А. Журавель / / Правничий часопис Донецького університету. - Донецьк, 2002. - Вип. 2 (8). C. $56-58$

13. Чернявський С.С. Фінансове шахрайство: методологічні засади розслідування : [монографія] / С.С. Чернявський. - К. : Хай-Тек Прес, 2010. - 624 с.

14. Волобуєв А.Ф. Проблеми методики розслідування розкрадань майна у сфері підприємництва / А.Ф. Волобуєв. - Х. : УН-т внутр. справ, 2000. - 336 с.

15. Тіщенко В.В. Теоретичні і практичні основи методики розслідування злочинів : [монографія] / В.В. Тіщенко ; Одеська нац. юрид. акад. - Одеса : Фенікс, 2007. - 260 с.

16. Розслідування торгівлі людьми : [навчальний посібник] / [M.I. Андрієнко, О.В. Бардацька, А.Ф. Волобуєв, В.Я. Горбачевський, В.І. Дубина та ін.] ; за ред. П.В. Коляди. - К. : Конус-Ю, 2009. - 190 c. 


\section{Ано т а ц і я}

Чорноус Ю. М. Міжнародна злочинність: актуальні завдання для криміналістичної методики. - Стаття.

У статті за сучасних реалій підкреслюється важливість опрацювання криміналістичної методики розслідування найбільш небезпечного виду злочинності - міжнародної.

Ключові слова: криміналістична методика, розслідування, міжнародні злочини, злочини міжнародного характеру, злочини «з міжнародними зв'язками», криміналістичні рекомендації.

\section{Анн н т а ци я}

Чорноус Ю. Н. Международная преступность: актуальные задачи для криминалистической методики. - Статья.

В статье в современных реалиях подчеркивается важность разработки криминалистической методики расследования наиболее опасного вида преступности - международной.

Ключевые слова: криминалистическая методика, расследование, международные преступления, преступления международного характера, преступления «с международными связями», криминалистические рекомендации.

\section{S u m m a r y}

Chornous $Y u$. M. International crime: a topical task for forensic techniques. - Article. For the modern realities highlights the importance of the study of forensic methods of investigation, the most dangerous form of crime is international.

Key words: forensic methods of investigation, international crimes, crimes of an international character, "crime with international ties", criminalistic recommendations. 